\title{
Did H Influence D on an Early or a Late Stage of the Redaction of $D$ ? 1
}

\author{
BENJAMIN KILCHÖR (STH BASEL, CH)
}

\begin{abstract}
Although $D$ is generally regarded as older than $H$, it has often been observed that $H$ also seems to have affected $D$. While this impact of $H$ on $D$ usually has been explained as a late redaction of $D$, it is argued in this paper by a few examples based on my dissertation that the impact of $H$ on $D$ rather should be seen as an impact on an early stage of the redaction of $D$. This short paper, which was first presented at the IOSOT Conference in Stellenbosch, is expanded by a postscript with a brief response to some points of the discussion
\end{abstract}

\section{A INTRODUCTION}

The idea for this article arose in the autumn 2015, when Prof. Hans Ulrich Steymans visited our faculty in Basel for a guest lecture. He had read at least parts of my dissertation Mosetora und Jahwetora ${ }^{2}$ where I argue that Deuteronomy not only presupposes the book of the Covenant, but also the Holiness Code, and he said that it is in his view in good accordance with the thesis of the Decalogue redaction of Georg Braulik.

While my dissertation is indeed strongly influenced and stimulated by Braulik's thesis of a Decalogue redaction, there are also fundamental differences in at least two issues. ${ }^{3}$ First, the Decalogue redaction is, according to

* Article submitted: 13/09/2016; accepted: 22/11/2016. To cite: Benjamin Kilchör, “Did H Influence D on an Early or a Late Stage of the Redaction of D?" OTE 29 (3) 2016: 502-512. Doi: http://dx.doi.org/10.17159/2312-3621/2016/v29n3a9

1 This article is produced in connection with my status as Research Associate at the Department of Ancient Languages and Cultures of the University of Pretoria. A preliminary version of this paper was presented at the first Pro Pent Session at IOSOT 2016 in Stellenbosch. I want to express my gratitude to proff. Jurie le Roux and Eckart Otto for the invitation to present this paper and I also want to thank the participants of the session for the discussion.

2 Benjamin Kilchör, Mosetora und Jahwetora: Das Verhältnis von Deuteronomium 12-26 zu Exodus, Levitikus und Numeri, BZABR 21 (Wiesbaden: Harrassowitz, 2015).

3 His thesis was first argued in Georg Braulik, Die deuteronomischen Gesetze und der Dekalog: Studien zum Aufbau von Deuteronomium 12-26, SBS 145 (Stuttgart: Katholisches Bibelwerk, 1991), and further elaborated in Georg Braulik, "Die dekalogische Redaktion der deuteronomischen Gesetze: Ihre Abhängigkeit von Levitikus 19 am Beispiel von Deuteronomium 22,1-12; 24,10-22 und 25,13-16," in Bundesdokument und Gesetz: Studien zum Deuteronomium, ed. Georg Braulik, HBS 4 
Braulik, related only to Deut 19-25, while Deut 12-18 was for the most part already given at the time of the Decalogue redaction. ${ }^{4}$ I have, however, argued that Deut 12-18 was influenced by $\mathrm{H}$ likewise. Secondly, Braulik seems to assume that the influence of $\mathrm{H}$ on the material of Deut 19-25 belongs to a late redactional stage where older Deuteronomic legal materials - single laws or law collections - are integrated into more general principles, which are provided by the exilic Decalogue. ${ }^{5}$ But I would suggest that the Deuteronomic law in many instances is just composed the other way around: the core of the laws is provided by material from $\mathrm{CC}$ or $\mathrm{H}$, while the Deuteronomic special material has the function of a redaction that presents the older laws in a new light. I show this below by a few examples which are taken from Deut 12-18.

In what follows, I shall not extensively argue either for the existence of a literary relationship between $\mathrm{H}$ and $\mathrm{D}$ or for the direction of dependence. I have done so in my dissertation and I do not have any additional arguments at the moment. Rather, I shall build upon these results and focus on the question, on what stage of redaction did $\mathrm{H}$ influence $\mathrm{D}$.

\section{B THE INFLUENCE OF H IN THE CORE OF DEUTERONOMY 12}

According to Thomas Römer it is "generally acknowledged that inside Deut. 12:1-19, vv. 13-18 constitute the kernel to which first vv. 8-12, then vv. 2-7 were added." 6 It is just in this kernel of Deut 12 where $H$ has the strongest impact. ${ }^{7}$ As Römer notes, Deut 12:13-18 "is mainly concerned with the practical consequences of the centralization law," namely with profane slaughtering. ${ }^{8}$ To be more precise, it deals with profane slaughtering of sacrificial animals (cattle, sheep and goats). Deut 12:15b explicitly presupposes established rules of the "profane" slaughtering of wild animals like gazelle and deer. The question that lies behind vv. 15-16 is therefore whether sacrificial animals which are slaughtered for profane use, should be slaughtered according to the rules of sacrificial animals or according to the rules of wild animals. We find respective rules in

(Freiburg i.Br.: Herder, 1995), 1-25, and Georg Braulik, "Weitere Beobachtungen zur Beziehung zwischen dem Heiligkeitsgesetz und Deuteronomium 19-25," in Das Deuteronomium und seine Querbeziehungen, ed. Timo Veijola, SFEG 62 (Göttingen: Vandenhoeck \& Ruprecht, 1996), 23-55.

4 See Braulik, Die deuteronomischen Gesetze, 116.

5 Braulik, Die deuteronomischen Gesetze, 117-118.

6 Thomas Römer, The So-Called Deuteronomic History: A Sociological, Historical and Literary Introduction (London: T\&T Clark, 2007), 57. Cf. Joachim Schaper, "Schriftauslegung und Schriftwerdung im alten Israel: Eine vergleichende Exegese von Ex 20,24-26 und Dtn 12,13-19," ZABR 5 (1999): 112-115; Eckart Otto, Deuteronomium 12,1-23,15, HThKAT (Freiburg i.Br.: Herder, 2016), 1147-1150.

7 See Kilchör, Mosetora und Jahwetora, 84-88.

8 Römer, Deuteronomic History, 60. 
Lev 3 and 17. There are two main distinctions: first, in the case of sacrifices the consumption of both fat and blood is forbidden, while in the case of wild animals only the consumption of blood is forbidden. Secondly, in the case of sacrifices the blood belongs to the altar, while in the case of wild animals the blood must be poured out and covered with earth. Deuteronomy 12:15b answers the question of the rules to be applied for profane slaughtering by stating that in case of profane slaughtering of sacrificial animals the animals shall be slaughtered according to the rules of "gazelle and deer," thus wild animals. Deuteronomy 12:16a then explains: רק הדם לא תאכלו - only the blood you must not eat. Why “only"? Because it quotes Lev 3:17, which by the way is regarded by some scholars ${ }^{9}$ as H: כל חלב וכל דם לא תאכלו - all fat and all blood you must not eat. "Only" therefore means: the fat is allowed to eat and "only" the blood is forbidden. Deuteronomy 12:16b continues: "You shall pour it out [e.g. the blood] on the ground like water." This is a hint to Lev 17:13, according to which the blood of wild animals must be poured out and covered with earth.

If Deut 12:13-18 constitutes the kernel of Deut 12, we have here an impact of $\mathrm{H}$ on Deuteronomy, not on a late but on an early stage of the redaction of D.

\section{THE DEUTERONOMIC SPECIAL MATERIAL IN 14:3-20}

The relationship between the laws of clean and unclean animals in Lev 11 and Deut 14 has been much discussed. ${ }^{10}$ The text is largely identical with only minor differences. Both texts have a few additions so that we do not merely have a shorter text that has been expanded by a later one. This has led some scholars to suggest that both versions build on an older, underlying source that is not preserved to us. ${ }^{11}$ I have, however, argued in agreement with Reinhard Achenbach that all differences are best explained by the priority of Lev 11.12

9 E.g. Christophe Nihan, From Priestly Torah to Pentateuch: A Study in the Composition of the Book of Leviticus, FAT II/25 (Tübingen: Mohr Siebeck, 2007), 569.

10 For a short overview on the state of research see Esias Meyer, "Leviticus 11, Deuteronomy 14 and Directionality,” JSem 23 (2014): 71-72.

11 E.g. Walter Houston, Purity and Monotheism: Clean and Unclean Animals in Biblical Law, JSOTSup 140 (Sheffield: Academic Press, 1993), 63-65; Naphtali S. Meshel, "Pure, Impure, Permitted, Prohibited: A Study of Classification Systems in P," in Perspectives on Purity and Purification in the Bible, ed. Baruch J. Schwartz, et al. (London: T\&T Clark, 2008), 33; Christophe Nihan, “The Laws about Clean and Unclean Animals in Leviticus and Deuteronomy and Their Place in the Formation of the Pentateuch,” in The Pentateuch: International Perspectives on Current Research, ed. Thomas B. Dozeman, Konrad Schmid and Baruch J. Schwartz, FAT 78 (Tübingen: Mohr Siebeck, 2011).

12 Reinhard Achenbach, "Zur Systematik der Speisegebote in Leviticus 11 und in Deuteronomium 14,” ZABR 17 (2011): 173; Kilchör, Mosetora und Jahwetora, 97108. 
What is of interest here is the place and function of the Deuteronomic special material within this common material. While Deut 14:4a is formulated parallel to Lev 11:2, and Deut 14:6 is almost identical to Lev 11:3, the Deuteronomic special material is added in Deut 14:4b-5. It presents a list of animals which are allowed to be eaten. It starts with the three sacrificial animals bull, ram, and goat, which are allowed for profane slaughter according to Deut 12:13-18. These three animals are listed together in the whole OT otherwise only in Lev 7:23, 17:3, 22:27, and Num 18:17. They are followed by deer and gazelle, the two wild animals of the comparison in Deut 12:15, and then by several further wild animals. With the combination of Lev 17:3 and Deut 12:15, we have exactly the results of the issue of Deut 12:13-18 as Deuteronomy's addition to the list of Lev 11.

I am aware that most scholars date Deut 14:3-20 very late as a postexilic and post priestly addition in Deuteronomy. ${ }^{13}$ However, the addition is inspired by Deut 12:13-18, which is regarded as the core of Deut 12 . And, more important, it is a clear case where we do not have older Deuteronomic legislation that is rearranged by a redaction that integrates the view of $\mathrm{P}$ or $\mathrm{H}$ into Deuteronomic material, but rather we have $\mathrm{P}$ or $\mathrm{H}$ material that is redactionally revised under the viewpoints of $\mathrm{D}$.

\section{THE DEUTERONOMIC SPECIAL MATERIAL IN 14:22-29}

The Deuteronomic law on the tithe does neither establish nor explain, but presuppose the tithe (vv. 22-23):

You shall tithe the tithe, all the yield of your seed, what grows on the field, year by year, and eat it before YHWH, your God, at the place that he will choose, to establish his name there: the tithe of your grain, of your wine, and of your oil, and the firstborn of your herd and flock, that you may learn to fear YHWH, your God, always.

The purpose of this law is not to establish the tithe as such, but rather to show what Deut 12 means with regard to the tithe. It is interesting to compare these two verses with the other two occurrences of the tithe in Pentateuchal legislation: Lev 27:30-33, and Num $18 .{ }^{14}$ In its short summary of what the tithe includes, Deut 14:22-23 combines these two former laws. While Num 18:30 describes the tithe as the "yield of the threshing floor and winepress," and Lev 27:30 describes it as "the seed of the land," Deut 14:22 describes it as the "yield of the seed." Furthermore, while Lev 27:32 lists the tithe of herds and

13 E.g. Achenbach, "Systematik"; Eckart Otto, "Das Buch Levitikus zwischen Priesterschrift und Pentateuch,” in Die Tora: Studien zum Pentateuch: Gesammelte Schriften, ed. Eckart Otto, BZABR 9 (Wiesbaden: Harrassowitz, 2009), 120-122; Römer, Deuteronomistic History, 171.

14 See Kilchör, Mosetora und Jahwetora, 115-125. 
flocks, and Num 18:12 lists the "best of the oil, wine, and grain" for the priest's share, Deut 14:23 combines both as "the tithe of your grain, of your wine, and of your oil, and the firstborn of your herd and flock."

Thus, Deut 14:22-23 refers back to the legislation on the tithe in Lev 27 and Num 18 by summarizing what the tithe includes, but it does so in order to show what the innovations of Deut 12 mean for the practice of the tithe. Deuteronomy 14:24 then goes on by taking up Deut 12:21 - the case that the way is too long - and applies the opportunity to turn it into silver, as we find it in Lev 27:15-19.31.

Again, the impact of these texts - be they $\mathrm{H}$ or even post- $\mathrm{H}$ - on Deuteronomy is not at the borders of an otherwise older Deuteronomic law, but in Deuteronomy's very core. We do not have a Deuteronomic law that is extended by some priestly thought, but we have the reference to priestly legislation in the core of the law, which is then elaborated by Deuteronomic special material. In other words: the Deuteronomic special material is written to supplement and explain the older material. We can visualize this by indenting the Deuteronomic special material against the core of the law: 15

You shall tithe the tithe, all the yield of your seed, what grows on the field, year by year,

and eat it before YHWH, your God, at the place that he will choose, to establish his name there:

the tithe of your grain, of your wine, and of your oil, and the firstborn of your herd and flock, that you may learn to fear $\underline{\text { YHWH}}$, your God, always.

But if the way is too long for you...

\section{E THE DEUTERONOMIC SPECIAL MATERIAL IN 15:19-23}

We can distinguish between the core of the law and the Deuteronomic special material in exactly the same way in Deut 15:19-23:16

All the male firstborn that is born among your herds and flockss you shall sanctify to YHWH your God.

You shall do no work with the firstborn of your herd, nor shear the firstborn of your flock: before YHWH, your God, you

15 The parallels with Lev 27:30-33 are underlined twofold, the parallels with Num 18 are underlined onefold.

16 See Kilchör, Mosetora und Jahwetora, 156-162. Parallels with Exod 22:28-29 are underlined dashed, parallels with Exod 13 are underlined onefold, and parallels with Lev 22 are underlined twofold. 
shall eat it, you and your household, year by year, at the place that YHWH will choose.

But if it has any blemish, if it is lame or blind or has any serious blemish whatever, you shall not sacrifice it to YHWH your God.

You shall eat it within your towns. The clean and the unclean alike may eat it, as though it were a gazelle or a deer. Only you shall not eat its blood; you shall poor it out on the ground like water.

The two parts of the core law are formulated in a parallelism: the firstborn shall be sanctified to YHWH, but what has a blemish shall not be sacrificed to YHWH. Again, we find the impact of other Pentateuchal laws, including $\mathrm{H}$, only in the core law, while the additions are Deuteronomic special material which explains the core law in light of Deut 12.

Deuteronomy 15:19a combines elements from Exod 22:28b-29a (firstborn, flock), from Exod 13:2, 11-16 (firstborn, male, sanctify to YHWH), and from Lev 22:18-25 (male, herd). Deuteronomy 15:21 then picks up further elements from Lev 22:18, namely "it has any blemish," "blind" and "not ... to YHWH.”

Thus, the impact of $\mathrm{H}$ on $\mathrm{D}$ affects the core of D's firstborn law and not its expansions.

\section{F CONCLUSION}

Such examples could be continued both in Deut 12-18 (e.g. the slave release law in Deut 15:12-1817 or the festival legislation in Deut 16:1-1718) and in Deut 19-25 (e.g. the law concerning cities of refuge in Deut 19:1-1319). They show that the idea of a former independent Deuteronomic law, which is just influenced by other Pentateuchal laws - be it CC, $\mathrm{P}$, or $\mathrm{H}$ - on a later redactional stage, is misleading. Rather, the Deuteronomic law is constructed as an explanation of older legislation (Deut 1:520) from beginning on. This means

17 See Kilchör, Mosetora und Jahwetora, 137-153.

18 See Shimon Gesundheit, Three Times a Year: Studies on Festival Legislation in the Pentateuch, FAT 82 (Tübingen: Mohr Siebeck, 2012), 99-111; Kilchör, Mosetora und Jahwetora, 183-201.

19 See Kilchör, Mosetora und Jahwetora, 224-237.

20 See Eckart Otto, "Mose, der erste Schriftgelehrte: Deuteronomium 1,5 in der Fabel des Pentateuch," in L'Ecrit et l'Esprit: Etudes d'histoire du texte et de théologie biblique, ed. Dieter Böhler, Innocent Himbaza and Philippe Hugo, OBO 214 (Fribourg: Academic Press, 2005), 273-284, contra Georg Braulik and Norbert Lohfink, "Deuteronomium 1,5 באר את התורה הזאת 'er verlieh dieser Tora Rechtskraft,"” in Textarbeit: Studien zu Texten und ihrer Rezeption aus dem Alten Testament und der 
Kilchör, “Did H influence D?,” OTE 29/3 (2016): 502-512

that we have a D-redaction of older material (including $\mathrm{H}$ ) and not a post-P- or post-H-redaction of Deuteronomic material. The answer to the question of the title of this paper should therefore be, in my view: $\mathrm{H}$ did influence $\mathrm{D}$ on a very early stage of the redaction of $\mathrm{D}$.

\section{G POSTSCRIPT: A BRIEF RESPONSE TO SOME OBJECTIONS}

In the discussion that followed to this short paper at the Pro Pent Session at the IOSOT 2016 in Stellenbosch, several objections have been raised against the thesis presented here. I want to give a brief response to three objections.

\section{The Consequences of a General Priority of $\mathbf{P} / \mathrm{H}$}

What does it mean for the dating of $\mathrm{H}$ and $\mathrm{D}$, if $\mathrm{H}$ is in general older than $\mathrm{D}$, as suggested by this paper? On the one hand, it could mean that even the core of Deuteronomy is much younger than commonly assumed. It was, however, rightly objected that this would raise serious problems with regard to all the texts of the HB, which are influenced by Deuteronomy. I therefore agree that it is hardly possible to date Deuteronomy much later. On the other hand, it could mean that several $\mathrm{P} / \mathrm{H}$ traditions must be older than commonly assumed and this is indeed my suggestion. However, the objection against an earlier dating of $\mathrm{P} / \mathrm{H}$ was that if $\mathrm{P} / \mathrm{H}$ was available for $\mathrm{D}$, then it must also have been available for other texts of the HB, especially for the Former Prophets who largely depend on core texts of Deuteronomy. Why then - thus the objection - do we not find evidence for the reception of $\mathrm{P} / \mathrm{H}$ in texts that reach back to the preexilic time? My short response to this objection is that we indeed have evidence for the reception of $\mathrm{P} / \mathrm{H}$ in such texts. Of course, I cannot go deeply into this issue here. However, the IOSOT 2016 provided at least two good examples.

First, in her excellent main paper with the title "The Forest and the Trees: The Place of Pentateuchal Materials in Prophecy of the Late Seventh / Early Sixth Centuries B.C.E.,” Dalith Rom-Shiloni argued that not only Ezekiel $^{21}$ but also Jeremiah presupposes H and D and conflates them. Since this pattern can be found throughout the book, in prose and poetic texts likewise, Dalith-Shiloni concluded that the influence of $\mathrm{H}$ cannot be reduced to late redactional stages of the book but that the prophet in the late seventh century must already have had access to some established priestly traditions, be they oral or written or, possibly, both.

Umwelt Israels, ed. Klaus Kiesow and Thomas Meurer, AOAT 294 (Münster: Ugarit, 2003), 35-51.

21 For Ezekiel see also Risa Levitt Kohn, A New Heart and a New Soul: Ezekiel, the Exile and the Torah, JSOTSup 358 (London: Sheffield Academic, 2002); Michael A. Lyons, From Law to Prophecy: Ezekiel's Use of the Holiness Code, LHBOTS 507 (New York: T\&T Clark, 2009). 
Secondly, each participant at IOSOT 2016 received a beautiful bag, which included the current issue of Old Testament Essays. In this issue Pekka Pitkänen has published a contribution with the title "The Use of Priestly Legal Tradition in Joshua and the Composition of the Pentateuch and Joshua."22 Pitkänen gives several examples where the book of Joshua not only presupposes $\mathrm{D}$ but also $\mathrm{P} / \mathrm{H}$.

We are here confronted with a serious methodological problem. Of course, "Priestly" influences have been found in the Former Prophets long ago. However, due to the overall chronological framework, they have been regarded as later redactional additions. When we exclude all priestly influences from the earliest stages of these texts it is no surprise that in the end we do not find influences of $\mathrm{P} / \mathrm{H}$ in early stages of the texts. But this is obviously circular reasoning.

\section{$2 \quad$ A Harmonizing Final Redaction?}

Another objection was that we should rather see the parallels between $\mathrm{H}$ and $\mathrm{D}$ as the intended work of a harmonizing final redaction of the Pentateuch, which tried to balance the tensions of these two former very different legal collections. This would mean that in their core, $\mathrm{H}$ and $\mathrm{D}$ are working with very different concepts and are addressing different issues, while $\mathrm{H}$ has some "Deuteronomic makeup" and D has some "Holiness makeup," applied by late redactors with the intention that they match a bit better within the composition of the Pentateuch.

Yet there are several problems with this suggestion. First, the Holiness Code has no "Deuteronomic makeup" at all. This observation already led scholars like Moshe Weinfeld and Jacob Milgrom to conclude that $\mathrm{P} / \mathrm{H}$ must be older than D. ${ }^{23}$ Secondly, as argued in this paper, the impact of $\mathrm{P} / \mathrm{H}$ on $\mathrm{D}$ does not just belong to the borders of Deuteronomy's laws but affects their core, while it is absent in the additional special material. Thirdly, and most important, the impact of $\mathrm{P} / \mathrm{H}$ on Deuteronomy can not only be seen in some vocabulary and formulations. Rather, Deuteronomy deals with the P and $\mathrm{H}$ laws on a conceptual level in a clearly reflected way, which shows no distinctions to the way Deuteronomy deals with the Covenant Code. I have elaborated the legal hermeneutics of Deuteronomy with regard to both CC and P/H in my dissertation ${ }^{24}$ and the result clearly is that Deuteronomy not only has some Priestly

22 Pekka Pitkänen, "Use of Priestly Legal Tradition in Joshua and the Composition of the Pentateuch and Joshua,” OTE 29 (2016): 318-335.

23 Cf. Moshe Weinfeld, Deuteronomy and the Deuteronomic School (Oxford: Clarendon, 1972), 180; Jacob Milgrom, Leviticus 17-22, AB 3A (New Haven: Yale University, 2000), 1357: "Moreover, it is indisputable that there are no traces of D's language or concepts in $\mathrm{H}$.”

24 Kilchör, Mosetora und Jahwetora. 
makeup, which can easily be removed, but that Deuteronomy essentially is composed as an engagement with the other Pentateuchal legal collections, following clear hermeneutical principles.

\section{The Lack of Absolute Dating}

Finally, it was criticised that I abstain from proposing an absolute dating for when $\mathrm{H}$ influenced $\mathrm{D}$. To be sure, I would be happy to be able to present absolute dating proposals. However, I have serious methodological concerns about the way in which Biblical texts are often dated. These concerns are best formulated by Benjamin Sommer's article "Dating Pentateuchal Texts and the Perils of Pseudo Historism,” first presented at a Pentateuch conference in Zürich in 2010. ${ }^{25}$ According to Sommer,

many scholars in our field insist on one or both of the following methodological propositions:

(i) We may discover a text's historical setting by speculating about what audience have found the text's ideas most meaningful.

(ii) We should interpret texts first and foremost on the basis of what we speculate may have been their historical contexts. ${ }^{26}$

To be sure, Sommer does not reject historical and diachronical investigation at all. However, he states that "a careful scholar needs to acknowledge that not all texts can be dated with precision."27 My reservation in presenting absolute dates for Pentateuchal texts too soon has not only to do with the fact that most dating suggestions in Pentateuchal research are in my view quite speculative, but also with the methodological problem that the presupposition of a speculative historical framework can make a person blind for observations, which do not fit the presupposed framework. Redaction criticism then serves as an instrument to immunise the proposed framework against basic criticism: whatever not fits the framework is regarded as a later redactional addition. One should therefore avoid, in my view, to be too fast at hand with datings, which are not very well justified. It is better to take a step back and look open minded to the relationship between texts and to allow for observations, which might not always fit the current presupposed frameworks.

\section{BIBLIOGRAPHY}

25 Benjamin Sommer, "Dating Pentateuchal Texts and the Perils of Pseudo-Historism," in The Pentateuch: International Perspectives on Current Research, ed. Thomas B. Dozeman, Konrad Schmid and Baruch J. Schwartz, FAT 28 (Tübingen: Mohr Siebeck, 2011), 85-108.

26 Sommer, "Dating Pentateuchal Texts," 101.

27 Sommer, "Dating Pentateuchal Texts," 106. 
Achenbach, Reinhard, "Zur Systematik der Speisegebote in Leviticus 11 und in Deuteronomium 14.” Zeitschrift für altorientalische und biblische Rechtsgeschichte 17 (2011): 161-209.

Braulik, Georg. Die deuteronomischen Gesetze und der Dekalog: Studien zum Aufbau von Deuteronomium 12-26. Stuttgarter Bibelstudien 145. Stuttgart: Katholisches Bibelwerk, 1991. . "Die dekalogische Redaktion der deuteronomischen Gesetze: Ihre Abhängigkeit von Levitikus 19 am Beispiel von Deuteronomium 22,1-12; 24,10-22 und 25,13-16.” Pages 1-25 in Bundesdokument und Gesetz: Studien zum Deuteronomium. Edited by Georg Braulik. Herders Biblische Studien 4. Freiburg i. Br.: Herder, 1995.

"Weitere Beobachtungen zur Beziehung zwischen dem Heiligkeitsgesetz und Deuteronomium 19-25.” Pages 23-55 in Das Deuteronomium und seine Querbeziehungen. Edited by Timo Veijola. Schriften der Finnischen Exegetischen Gesellschaft 62. Göttingen: Vandenhoeck \& Ruprecht, 1996.

Braulik, Georg and Norbert Lohfink. "Deuteronomium באר את התורה הזאת ex 'ex 'ex verlieh dieser Tora Rechtskraft.”’ Pages 35-51 in Textarbeit: Studien zu Texten und ihrer Rezeption aus dem Alten Testament und der Umwelt Israels. Edited by Klaus Kiesow and Thomas Meurer. Alter Orient und Altes Testament 294. Münster: Ugarit, 2003.

Gesundheit, Shimon. Three Times a Year: Studies in Festival Legislation in the Pentateuch. Forschungen zum Alten Testament 82. Tübingen: Mohr Siebeck, 2012.

Houston, Walter. Purity and Monotheism: Clean and Unclean Animals in Biblical Law. Journal for the Study of the Old Testament Supplement Series 140. Sheffield: Academic Press, 1993.

Kilchör, Benjamin. Mosetora und Jahwetora: Das Verhältnis von Deuteronomium 12-26 zu Exodus, Levitikus und Numeri. Beihefte zur Zeitschrift für altorientalische und biblische Rechtsgeschichte 21. Wiesbaden: Harrassowitz, 2015.

Levitt Kohn, Risa. A New Heart and a New Soul: Ezekiel, the Exile and the Torah. Journal for the Study of the Old Testament Supplement Series 358. London: Sheffield Academic Press, 2002.

Lyons, Michael A. From Law to Prophecy: Ezekiel's Use of the Holiness Code. The Library of Hebrew Bible/Old Testament Studies 507. New York: T\&T Clark, 2009.

Meshel, Naphtali. "Pure, Impure, Permitted, Prohibited: A Study of Classification Systems in P." Pages 32-42 in Perspectives on Purity and Purification in the Bible. Edited by Baruch J. Schwartz, Naphtali S. Meshel, Jeffrey Stackert and David P. Wright. London: T\&T Clark, 2008.

Meyer, Esias. "Leviticus 11, Deuteronomy 14 and directionality.” Journal for Semitics 23 (2014): 71-89.

Milgrom, Jacob. Leviticus 17-22. Anchor Bible 3A. New Haven: Yale University Press, 2000.

Nihan, Christophe. From Priestly Torah to the Pentateuch: A Study in the Composition of the Book of Leviticus. Forschungen zum Alten Testament II/25. Tübingen: Mohr Siebeck, 2007. 
512 Kilchör, “Did H influence D?,” OTE 29/3 (2016): 502-512

. "The Laws about Clean and Unclean Animals in Leviticus and Deuteronomy and Their Place in the Formation of the Pentateuch.” Pages 401-432 in The Pentateuch: International Perspectives on Current Research. Edited by Thomas Dozeman, Konrad Schmid and Baruch J. Schwartz. Forschungen zum Alten Testament 78. Tübingen: Mohr Siebeck, 2011.

Otto, Eckart. "Mose, der erste Schriftgelehrte: Deuteronomium 1,5 in der Fabel des Pentateuch.” Pages 273-284 in L'Ecrit et l'Esprit: Etudes d'histoire du texte et de théologie biblique. Edited by Dieter Böhler, Innocent Himbaza and Philippe Hugo. Orbis Biblicus et Orientalis 214. Fribourg: Academic Press, 2005. . "Das Buch Levitikus zwischen Priesterschrift und Pentateuch.” Pages 107-142 in Die Tora: Studien zum Pentateuch: Gesammelte Schriften. Edited by Eckart Otto. Beihefte zur Zeitschrift für altorientalische und biblische Rechtsgeschichte 9. Wiesbaden: Harrassowitz, 2009.

. Deuteronomium 12,1-23,15. Herders Theologischer Kommentar zum Alten Testament. Freiburg i.Br.: Herder, 2016.

Pitkänen, Pekka. "The Use of Priestly Legal Tradition in Joshua and the Composition of the Pentateuch and Joshua.” Old Testament Essays 29 (2016): 318-335.

Römer, Thomas. The So-Called Deuteronomistic History: A Sociological, Historical and Literary Introduction. London: T\&T Clark, 2007.

Schaper, Joachim. "Schriftauslegung und Schriftwerdung im alten Israel: Eine vergleichende Exegese von Ex 20,24-26 und Dtn 12,13-19.” Zeitschrift für altorientalische und biblische Rechtsgeschichte 5 (1999): 111-132.

Sommer, Benjamin. "Dating Pentateuchal Texts and the Perils of Pseudo-Historism." Pages 85-108 in The Pentateuch: International Perspectives on Current Research. Edited by Thomas B. Dozeman, Konrad Schmid and Baruch J. Schwartz. Forschungen zum Alten Testament 78. Tübingen: Mohr Siebeck, 2011.

Weinfeld, Moshe. Deuteronomy and the Deuteronomic School. Oxford: Clarendon, 1972.

Benjamin Kilchör, Assistant Professor of Old Testament at Staatsunabhängige Theologische Hochschule Basel, Switzerland \& Research Associate at the Department of Ancient Languages and Cultures, University of Pretoria, South Africa.Email: benjamin.kilchoer@sthbasel.ch. 